\title{
Scandinavian Neuroscience during the Nazi Era
}

\author{
Daniel Kondziella, Klaus Hansen, Lawrence A. Zeidman
}

\begin{abstract}
Although Scandinavian neuroscience has a proud history, its status during the Nazi era has been overlooked. In fact, prominent neuroscientists in German-occupied Denmark and Norway, as well as in neutral Sweden, were directly affected. Mogens Fog, Poul Thygesen (Denmark) and Haakon Sæthre (Norway) were resistance fighters, tortured by the Gestapo: Thygesen was imprisoned in concentration camps and Sæthre executed. Jan Jansen (Norway), another neuroscientist resistor, escaped to Sweden, returning under disguise to continue fighting. Fritz Buchthal (Denmark) was one of almost 8000 Jews escaping deportation by fleeing from Copenhagen to Sweden. In contrast, Carl Værnet (Denmark) became a collaborator, conducting inhuman experiments in Buchenwald concentration camp, and Herman Lundborg (Sweden) and Thorleif Østrem (Norway) advanced racial hygiene in order to maintain the "superior genetic pool of the Nordic race." Compared to other Nazi-occupied countries, there was a high ratio of resistance fighters to collaborators and victims among the neuroscientists in Scandinavia.
\end{abstract}

RÉSUMÉ: Les neurosciences en Scandinavie pendant la période nazie. Bien que l'histoire éminente des neurosciences en Scandinavie soit reconnue à juste titre, son statut pendant la période nazie a été passé sous silence. En fait, des neuroscientifiques éminents au Danemark et en Norvège, deux pays occupés par les nazis, ainsi qu'en Suède, un pays neutre, ont été directement touchés. Mogens Fog, Poul Thygesen (Danemark) et Haakon Saethre (Norvège) étaient des combattants de la résistance qui ont été torturés par la Gestapo, Thygesen a été emprisonné dans des camps de concentration et Saethre a été exécuté. Jan Jansen (Norvège), un autre neuroscientifique résistant, a fui en Suède et il est retourné dans son pays sous déguisement pour continuer de combattre. Fritz Buchthal (Danemark) était parmi environ 8000 Juifs qui ont échappé à la déportation en fuyant Copenhague pour se réfugier en Suède. Par contre, Carl Vaernet (Danemark) est devenu collaborateur et il a réalisé des expériences inhumaines au camp de concentration de Buchenwald, et Herman Lundborg (Suède) et Thorleif Østrem (Norvège) ont fait la promotion de l'hygiène raciale pour maintenir le « pool génétique supérieur de la race nordique ». Si l'on compare la Scandinavie aux autres pays occupés par les nazis, il y a eu un taux élevé de combattants de la résistance par rapport aux collaborateurs et les victimes chez les neuroscientifiques.

Can J Neurol Sci. 2013; 40: 493-503

When Nazi Germany invaded Denmark and Norway on April 9, 1940, the Norwegian government and king went into exile to London, whereas the Danish government adopted a policy of cooperation, allowing for mutual concessions, e.g. the continued existence of the Danish government, legislature and judiciary, and the initial protection of Danish Jews and communists. This cooperation officially ended on August 29, 1943, when increasing tensions in the population progressed into strikes and street fighting. Encouraged by the news of German defeats in North Africa and Russia, the formerly docile Danish resistance movement initiated a series of forceful sabotage acts, akin to those in Norway. Moreover, in what has been called "the world's most fabulous escape," the Danes helped more than 7000 Jews in October 1943 to flee Copenhagen and Zealand into safety in neutral Sweden, ${ }^{1}$ which at this stage had given up its positive position toward Nazi Germany, eager to establish itself as a supporter of the Allies., 2,3

Scandinavian neuroscience has a proud history, but the experiences of neuroscientists during 1940-45 have been largely neglected in the literature. ${ }^{4}$ This paper therefore examines representative biographies of affected Scandinavian neuroscientists during World War II (WWII) and analyzes their fates in the historical context.*
For the sake of convenience, the neuroscientists are grouped similarly to Holocaust historian Raul Hilberg's classification, albeit in a modified fashion, into resistance fighters (Mogens Fog, Poul Thygesen/Denmark; Haakon Sæthre, Jan B. Jansen/Norway), refugees (Fritz Buchthal/Denmark) and collaborators and/or racial hygienists (Carl Værnet/Denmark; Herman B. Lundborg/Sweden; Thorleif D. Østrem/Norway). To our knowledge, a comprehensive analysis of Scandinavian neuroscience during the Nazi era has not been previously undertaken to this extent.

*The term "neuroscience" is a more modern term used here for expediency to describe the combination of clinical neurologists, neuropathologists, and neuropsychiatrists discussed in this paper, though the term did not exist in the 1930's and 40's. The term "Scandinavia" is used in its strictest, historical-linguistic definition and includes Denmark, Norway and Sweden.

From the Department of Neurology (DK, KH), Rigshospitalet, Copenhagen University Hospital, Denmark; Department of Neurology and Rehabilitation (LAZ),

Neuropsychiatric Institute, University of Illinois at Chicago, Chicago, Illinois, USA Received January 8, 2013. Final Revisions Submitted February 20, 2013. Correspondence to: Daniel Kondziella, Department of Neurology, Rigshospitalet, Copenhagen University Hospital, Blegdamsvej 9; DK-2100 Copenhagen.

Email: daniel_kondziella@yahoo.com. 


\section{METHODS}

Interviews with remaining colleagues and family members of the Scandinavian physicians listed in this paper were conducted, and information was corroborated by written records, both primary documentation and secondary medical and WWII literature. All translations from German, Danish, Norwegian and Swedish references are the authors' translations.

\section{RESULTS}

\section{Resistance fighters}

One of the most central members of the Danish resistance was Mogens Fog (1904-1990; Figure 1). Born into a liberal home in fashionable Frederiksberg in the Greater Copenhagen area, Fog became a communist when faced with the economic collapse following World War I. Despite rapidly advancing in the ranks of the Danish communist party (DKP), Fog left politics in the 1930s in order to focus on his medical career. In 1934 he submitted his thesis, "On the vasomotoric reactivity of leptomeningeal arteries." Only four year later he became consultant at Rigshospitalet, Copenhagen University Hospital, and Professor of Neurology at Copenhagen University, having outperformed much more senior competitors. The German

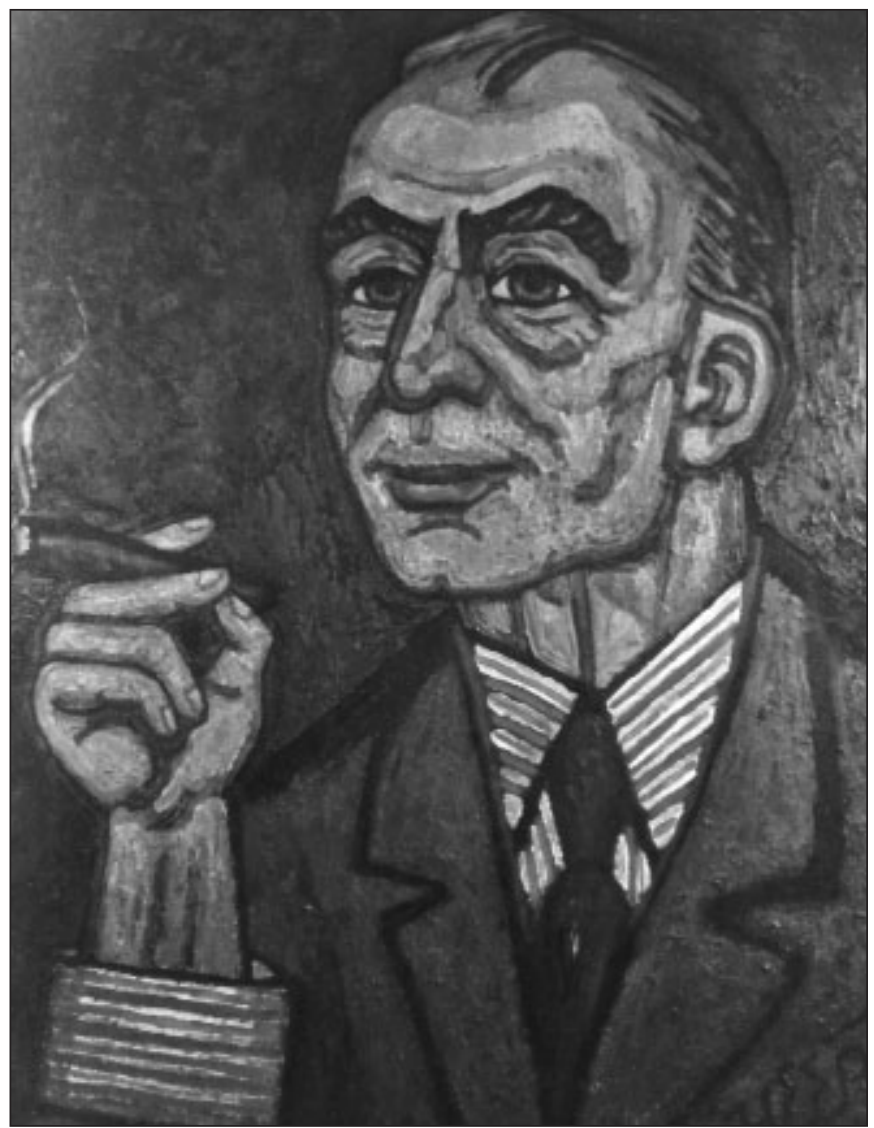

Figure 1: Mogens Fog (1904-1990). This oil portrait of Mogens Fog, painted by Henry Heerup in 1964 on the occasion of Fog's 60th birthday, is on display at the Department of Neurology, Rigshospitalet, Copenhagen University Hospital. (Photo by the authors) occupation in April 1940, however, caused a re-emergence of Fog's political and revolutionary convictions. ${ }^{5} \mathrm{He}$ helped hide resistance fighters by admitting them under false diagnoses at Rigshospitalet. In 1941, during a disguised patient consultation for migraine headache he accepted the invitation from DKP leader Axel Larsen to join the resistance himself. Fog's bourgeois background as a charming neurology professor with a fashionable villa in the Copenhagen suburbs on the one hand, and his earlier commitment to the DKP on the other, made him the perfect mediator between right and left wing resistance groups. He became leader of the nonpartisan (but primarily communist) resistance group Frit Danmark (Free Denmark) and the illegal newspaper of the same name, and he collaborated with the British Special Operations Executive who smuggled explosives and paratroopers into Denmark. In September 1943 Fog became one of the central figures in Denmark's Freedom Council (Frihedsråd). He wrote crucial letters and documents that inspired thousands of Danes to stop cooperating with the German occupiers and instead join the resistance:

'There is so little we can do' is yet another traditional remark during debates in Danish living rooms. Right, but if all had said that, Hitler would rule the world today [...]. 'Drops in the ocean', you say now - well, the oceans are made up of drops, and nothing is too small in a movement [such as ours], every straw blade that we put in the Nazis' way is important. [...] All humans should have access to life's goods, regardless of birth, regardless of intellectual and economic resources, regardless of skin color and nationality - [all that we ask is that] they make an effort in community life for the common benefit according to their abilities. [...] The Nazis' agendas are in every aspect the exact opposite of mine, and therefore I had to fight them. [...] When the very foundation of my spiritual existence is threatened, when others fight for my beliefs, I cannot remain a passive observant. [...] We do not aim for heroism; we just want to be soldiers [...] who confront the enemies of our culture. ${ }^{6}$

When learning in December 1943 that his participation in the resistance had become known to the Gestapo, the secret police of Nazi Germany and German-occupied Europe, Fog left his family (who later fled to Sweden) and went into hiding. He plucked his eyebrows, grew a moustache and continually changed hair and clothing styles, address and daily routines. Fog (alias From, Henriksen, Holm, Ole, Orange, and the Engineer) was wanted by both the Gestapo and the Danish police. After nearly two years in the resistance Fog was captured by the Gestapo; his comrade was gunned down when trying to flee, and although Fog immediately realized that it was too late to help, he asked for his doctor's bag, hoping (in vain) to create an opportunity for escape. During the following five months he was tortured in Gestapo headquarters in central Copenhagen. Together with other political opponents he was imprisoned in the upper floor of the building, functioning as a living shield against possible Allied air raids. Believing that Fog otherwise would be doomed to death, his fellow resistance fighters planned a spectacular rescue operation. However, in the meantime the Allies had decided to destroy the headquarters in order to prevent leakage of crucial information on Danish resistance to the Gestapo. Fog survived the bombings of March 21, 1945, against all odds. He 


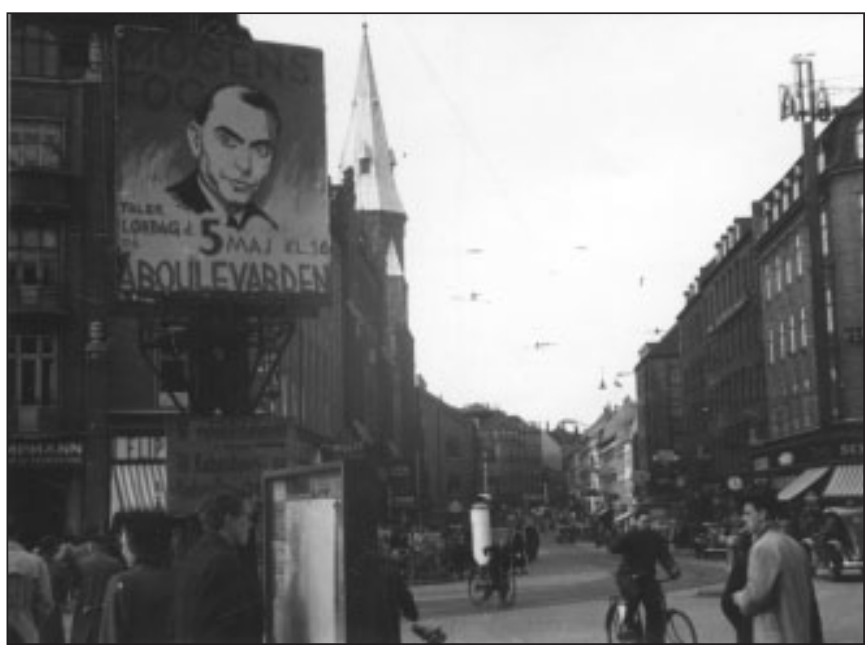

Figure 2: "Speaks on Saturday, May 6, 4pm, at Åboulevarden.” Mogens Fog was an exceedingly popular political figure after WWII due to his central position in the Danish resistance, although this popularity was only short-lived when Fog's communist background became known during the Cold War. (Courtesy of The Workers' Museum \& The Labour Movement's Library and Archives, Copenhagen)

escaped, climbing over corpses and debris, and just 20 minutes later he was enjoying a beer at a nearby pub to celebrate his escape. He rejoined the resistance and negotiated the formation of a new Danish government, since it became clear that the last days of the German occupation had come. Being aware that public opinion in Denmark was not in favor of a post-war communist take-over, he concealed all revolutionary intentions. ${ }^{7}$ Since Fog was held in high regard by the Danish public (Figure 2), he became Minister for Special Affairs in the Danish government from May to October 1945, in which his main task was to compensate resistance members and victims of the German occupation, as well as to organize the transport home of Danish concentration camp prisoners. Fog was Minister for the DKP from 1945 until 1950, but later he quit the party in protest of the USSR invasion of Hungary and co-founded the Socialistisk Folkeparti (Socialist Peoples' party). In January 1946 he returned to his work as Professor and Head of the neurology department at Rigshospitalet. His research was focused on cerebrovascular physiology and the epidemiology of multiple sclerosis. Fog was rector of Copenhagen University from 1966-72.

Poul Thygesen (1914-1999; born in Copenhagen) had just graduated from medical school when his interest in neurology brought him together with Mogens Fog. Thygesen became an intern in Fog's department at Rigshospitalet and a member (and later secretary) of Frit Danmark as well as editor of its newspaper. "Per" (Thygesen) went underground and helped gather intelligence on German fortifications and airfields in Denmark, and sent it via Sweden to England. He regularly met with "Holm" (Fog) and provided medical care for resistance fighters, among them the legendary "Citronen" (Danish, the Lemon). ${ }^{5}$ Thygesen was arrested on August 2, 1944, by the Gestapo, and interrogated and tortured at Vestre Fængsel prison in Copenhagen. On August 25, he was transferred to Frøslev prison camp, close to the German border, and on September 15

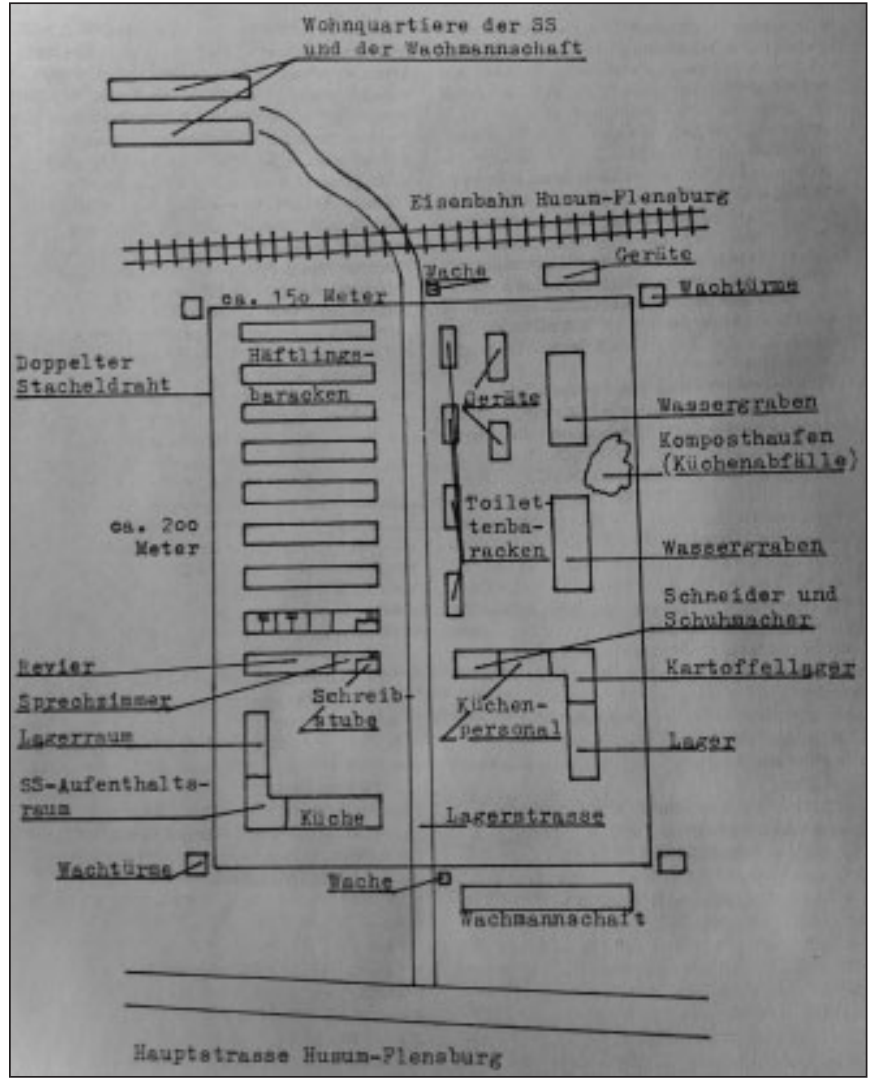

Figure 3: Apart from this sketch of Husum camp, Northern Germany, Poul Thygesen provided detailed written accounts on life and death in Nazi concentration camps, only a few months after his liberation by the Swedish Red Cross. German-English translations; Wohnquartiere der SS und der Wachmannschaft - housing blocks of SS and watchmen; Eisenbahn Husum-Flensburg - railway Husum-Flensburg; Wache guard; Geräte - equipment; Wachtürme - watchtowers; Doppelter Stacheldraht - double barbed wire; Häftlingsbaracken - prisoner barracks; Wassergraben - moat; Komposthaufen (Küchenabfälle) compost pile (kitchen waste); Toilettenbaracken - toilet barracks; Schneider und Schumacher - tailor and shoemaker; Küchenpersonal kitchen staff; Kartoffellager - potato storage; Lager/Lagerraum storeroom; Revier - hospital; Sprechzimmer - consulting room; Schreibstube - writing desk; SS-Aufenthaltsraum - sitting room for SS staff; Küche - kitchen; Lagerstrasse - camp road; Wachmannschaft guards; Hauptstrasse Husum - Flensburg - Main road HusumFlensburg. (Courtesy of Gedenkstätte Neuengamme, Hamburg)

to Neuengamme concentration camp near Hamburg. Eleven days later he was relocated to Husum, one of more than 80 Neuengamme subcamps. Here 2500 prisoners from 14 countries were forced to provide "totaler Arbeitseinsatz" (German, total labor commitment) for Friesenwall, an anti-tank trench in the swampy marshlands of Schleswig-Holstein and part of Germany's Atlantic wall, a system of fortifications along Europe's west coast as a defense against an Allied invasion (Figure 3). Thygesen served as a camp physician; in Husum he had virtually no medical equipment to treat more than 700 prisoner-patients. When the camp closed on December 29, 1944, Thygesen was transported to Meppen-Dalum, another Neuengamme subcamp; the train journey lasted for seven days 


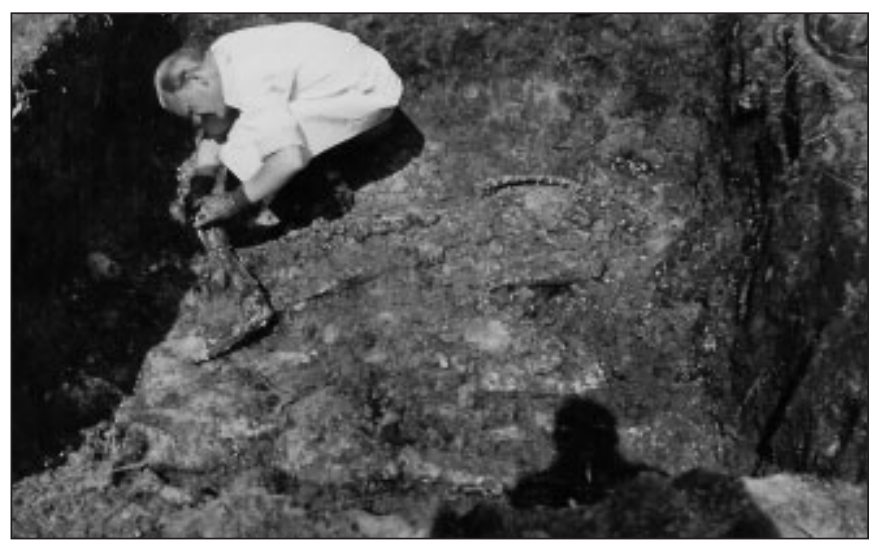

Figure 4: This photo shows Poul Thygesen (1914-1999) during the exhumation of Danish victims at Husum concentration camp, in 1945/46. (Courtesy of Frihedsmuseet, Copenhagen)

despite a distance of less than 400 kilometers. Two months later Thygesen again had to endure three days transport in a sealed and overcrowded railway carriage heading back to Neuengamme - without access to food, water or a lavatory; hence a high death toll. He was liberated on April 26, 1945 by the Swedish Red Cross. Only five months later he provided a 175 page account of his experiences in Germany. Although essentially forgotten today and never translated into English, it is a detailed account of life and death in a Nazi concentration camp. ${ }^{8}$ Assisted by the Danish government and the British military government in Northern Germany, Thygesen supervised the exhumation of Danish concentration camp victims in Husum during Winter $1945 / 1946$. Using dental records he was able to identify nearly all of the 21 Danish victims and arrange for transportation to their places of origin in Denmark (Figure 4). ${ }^{9}$ In 1953 Thygesen submitted his doctoral thesis on multiple sclerosis; four years later he became Head of Neurology at Gentofte Hospital, a teaching hospital in the Copenhagen region, and in 1970 he became Professor of Neurology at Copenhagen University. Thygesen contributed pioneering works on the so-called "concentration camp syndrome," which influenced legislation on compensation of WWII victims in many European countries. ${ }^{10}$ Also, in an article in the Danish newspaper Politiken from August 1947 he referred to Carl Værnet's Buchenwald experiments, thereby increasing awareness in the public (and in the Ministry of Justice) of the war crimes committed by the Danish SS physician, as discussed below.

Haakon Sathre (1891-1945; Figure 5) was a Norwegian neurologist and psychiatrist, highly concerned with children's psychiatric welfare in Oslo, who helped nurture and modernize his specialties (for a recent paper on Sæthre's biography, see Zeidman, 2013). ${ }^{11}$ Although he was the head of the psychiatric department at Ullevål University Hospital in Oslo, Sæthre continued a private neurology practice in the city and also served as neurology consultant at Ullevål. He had an interest in cerebrospinal fluid chemistry, founded a laboratory at Ullevål and published several papers on cerebrospinal fluid abnormalities associated with syphilils, encephalitis and poliomyelitis. In 1931 he described Sæthre-Chotzen syndrome (later named acrocephalosyndactyly type III, a rare congenital disorder associated with craniosynostosis and defects of the hands and feet), ${ }^{12,13}$ which was also described by German psychiatrist Fritz Chotzen the following year. ${ }^{14}$ His immense patriotism was likely developed from his youth when he witnessed Norway gain independence from Sweden. Thus when Germany occupied Norway during WWII Sæthre actively resisted, first revoking his Norwegian Medical Association membership, then hiding 12 persecuted Jews as patients in his ward at Ullevål and aiding in their flight to Sweden, as well as managing the largest "illegal" food warehouse in Oslo that contained Danish humanitarian aid. From 1942 on the food was stored in the basement of the psychiatry department at Ullevål and distributed to underground resistance fighters, prisoners and others in need. Sæthre was one of 34 Norwegians executed just before the war's end by the Nazis in reprisal for the resistance's assassination of hated Norwegian Nazi Police Chief Karl Marthinsen. His legacy lives on in Norway, where he was

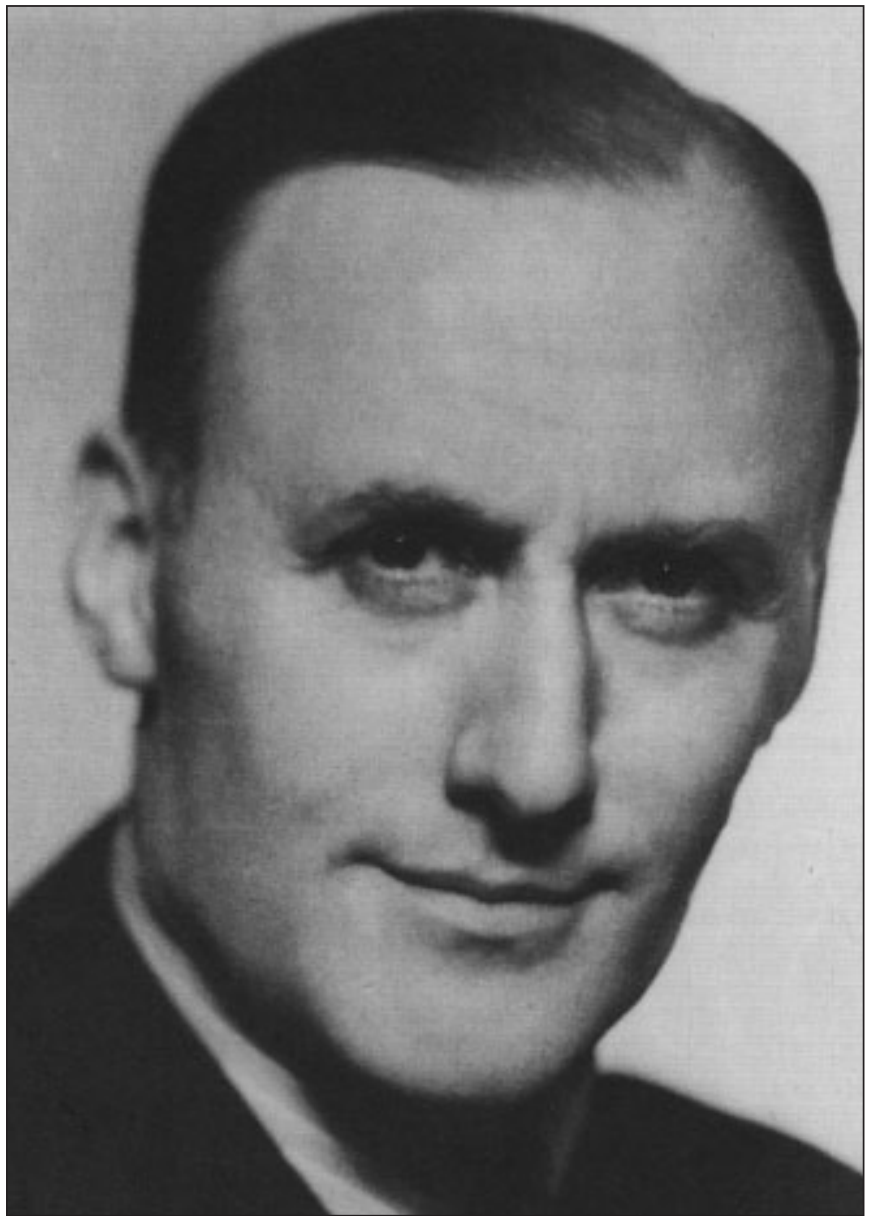

Figure 5: Haakon Sathre (1891-1945). Photo reprinted by permission from Peter Beighton, Emeritus Professor of Human Genetics, University of Cape Town, Cape Town, South Africa. Photo originally provided by Dr. Sigvald Refsum (1907-1991) from Norway, and published in Beighton P, Beighton G. The person behind the syndrome. London: Springer-Verlag; 1997. 


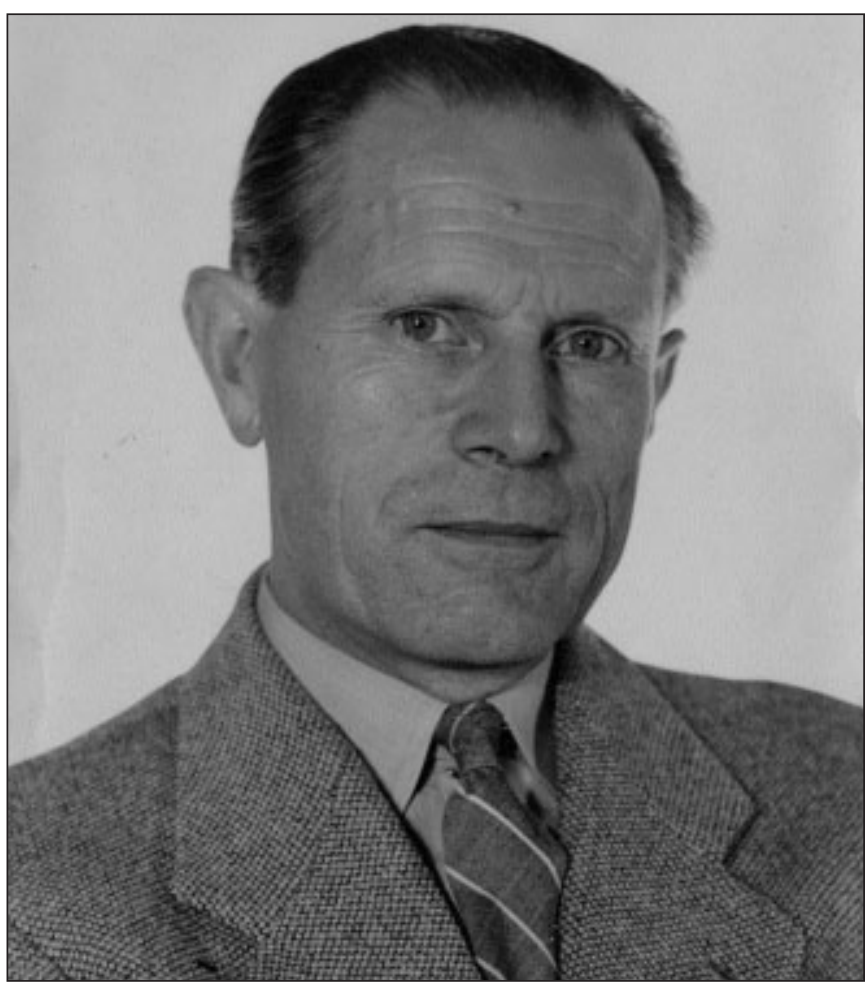

Figure 6: Jan Birger Jansen (1898-1984). (Courtesy of Oregon Health \& Science University, Historical Collections \& Archives, Portland, Oregon)

remembered by a portrait and plaques at Ullevål University Hospital, honored by a scholarship fund in his name, and a street was named after him in his hometown of Bergen. ${ }^{11}$

Jan Birger Jansen (1898-1984; Figure 6) graduated in 1924 from the University in Oslo (then, Christiana). From 1927-1929 he studied comparative neuroanatomy with a Rockefeller scholarship at the University of Chicago, and later in Amsterdam. In 1938 Jansen started the brain research laboratory at the department of anatomy in Oslo with the support from the Rockefeller Foundation, and he managed to create a research environment "where everyone felt appreciated and would do their best." Together with his former student Alf Brodal (19201988) he founded the so-called Oslo school of neuroanatomy, world famous for its pioneering studies of the cerebellum and its neuronal connections. Jansen was an "inspiring and accurate teacher, always well prepared." He wrote and revised several textbooks on anatomy and histology. With his "modesty and discretion" he was able to play a central part in the Norwegian resistance without hardly anyone, not even close colleagues and friends, noticing. When the Norwegian Medical Association was put under interim Nazi leadership in June 1941, a few physicians started the illegal legefront (physicians' front), among them were Jansen and Brodal. Jansen joined the editorial board of the Bulletinen, the most influential of the illegal newspapers in Norway and for many the "official organ of the Norwegian resistance movement." From 1942 he edited the newspaper alone, and for long periods he was its only writer. He organized a circle of medical students who helped distribute the newspaper.
In addition, Jansen was a member of Kretsen and Koordinasjonskomiteen, two of the most central organizations in the Norwegian resistance movement. ${ }^{15,16} \mathrm{He}$ had to flee to Sweden in late 1944 but managed to come back in disguise during Winter 1944/45 and to continue working for the resistance. After WWII Jansen was appointed "Commander of the Order of St. Olav", and he received the "Fridtjof Nansen Prize" and honorary doctorates from the universities in Kiel, Leiden and Aarhus.

Prominent Norwegian neuroscientists who, in contrast to Sæthre and Jansen, resisted more passively include Asbjørn Følling (1888-1972; describer of phenylketonuria) and Sigvald Refsum (1907-1991; describer of "heredopathia atactica polyneuritiformis," better known as Refsum's disease). Følling and Refsum did not publish any of their research during WWII because it was considered unpatriotic during the occupation, and Følling provided his laboratory to the Norwegian resistance to perfect the invisible ink used by the resistance to communicate undetected throughout the war. ${ }^{17-19}$ Medical student resistors who went on to become prominent neuroscientists include Norwegian Henrik Hartmann (1920-2007; later neuropathologist at the University of Wisconsin-Madison, US), who fought in Northern Norway as part of a ski patrol battalion of resistance fighters, ${ }^{20}$ and Dane Erik Skinhøj (1918-1983; Professor of Neurology, and rector of Copenhagen University, 1979-1982), who collaborated during the occupation with Mogens Fog, among others. ${ }^{21}$

\section{Refugees}

Fritz Buchthal (Figure 7) was born in Witten, Westphalia, Germany, in 1907 into a Jewish family. After one semester of medical school in Freiburg, he transferred temporarily to Stanford University in California in protest of the rising German Nationalism. After graduation he joined the Kaiser Wilhelm Institute of Biology in Berlin, where he developed microelectrodes to record single muscle fiber potentials. In 1933 after Hitler came to power, the Nazi regime passed the 'Law for the Restoration of the Professional Civil Service' which was intended to remove Jewish and other civil servants of "nonAryan' descent from their posts. Soon a similar law was passed that targeted other professional groups including doctors and lawyers. A complete surprise, "one morning in April [1933], some of my colleagues appeared in my office in SS uniform [asking me] to remove my personal effects [and] to leave the Institute for good" (Buchthal, unpublished autobiography, kindly provided to the authors by Professor C. Krarup, Copenhagen). Buchthal applied for a position in Copenhagen and was offered a stipend; there he worked on striated muscle fiber physiology. During the German occupation of Denmark, Buchthal fled to neutral Sweden:

In the evening [of September 29, 1943, we were driven] to the harbor south of Copenhagen, where a fishing boat was waiting. Among the passengers was Niels Bohr [Nobel Laureate in Physics and later participant in the Manhattan Project]. While we were waiting under deck we heard shooting not far away. Some of us were loaded in herring boxes, the size of coffins, which were then covered. We could hear the Germans on deck above us, 


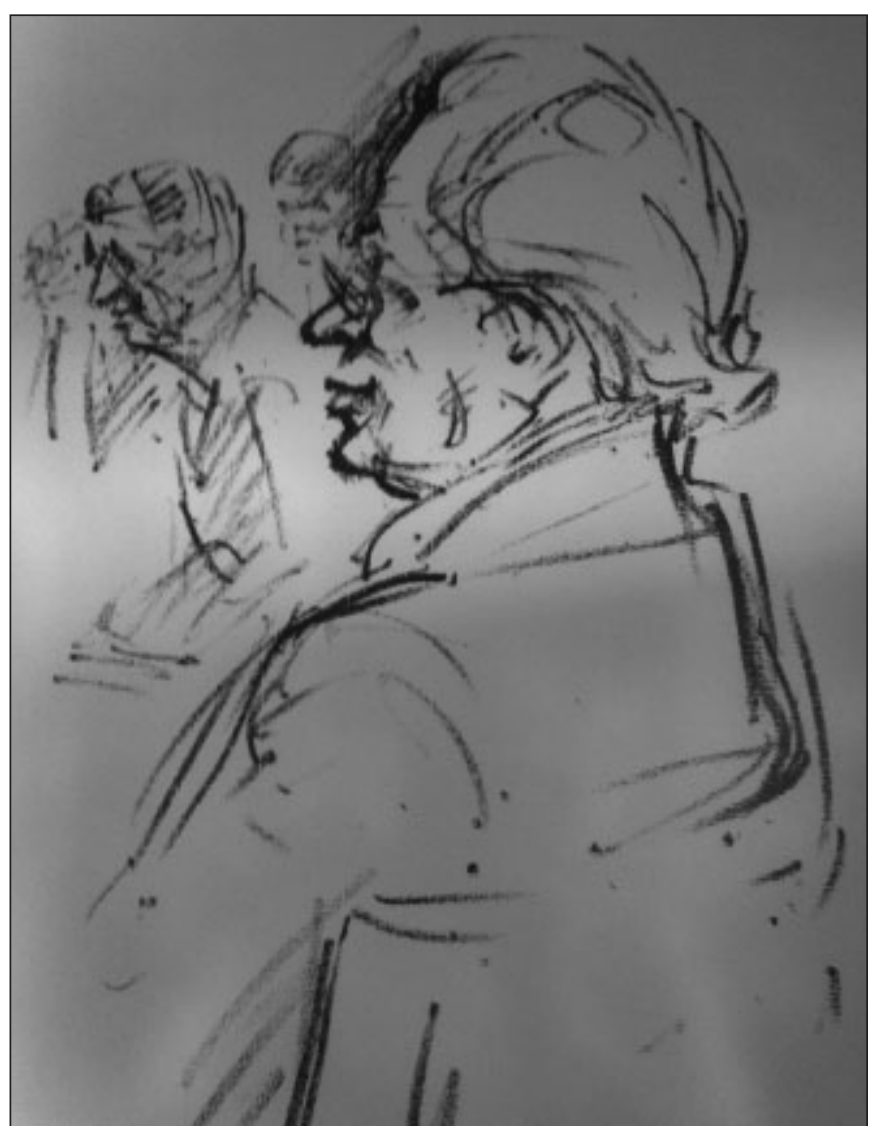

Figure 7: The portrait of Fritz Buchthal (1907-2003) is on display at the Department of Neurophysiology, Rigshospitalet, Copenhagen University Hospital. (Photo by the authors)

inspecting the boat. To add to our discomfort the boat motor refused to start for several minutes. Finally it started and we sailed to the middle of the sound to Swedish waters where we were loaded into another boat, which brought us to Landskrona harbour. (Buchthal, unpublished autobiography)

The journey over the Sound, the strait that separates the Danish island Zealand from the southern Swedish province of Scania, was not without risk; several times the boat had to turn off the engines in order to avoid being detected by patrolling vessels. In Sweden Buchthal worked at Lund University's Institute of Physiology and volunteered to care for released prisoners from German concentration camps, until he returned to Copenhagen in 1945. The following year he became a Danish citizen. At the recommendation of Niels Bohr and other scientists and supported by the Carlsberg and Rockefeller Foundations, Buchthal became Director of the newly established Institute of Neurophysiology in 1952 (Figure 7). He was appointed Professor of Neurophysiology in 1955 at Copenhagen University and was one of the first to introduce quantitative electromyography. Among Buchthal's most significant contributions were the characterization and quantification of the motor unit and its electrical activity using novel recording devices including concentric, bipolar, and multi-lead electrodes.
Buchthal moreover improved the study of nerve conduction by introducing the near-nerve stimulating and recording technique in order to also be able to record evoked potentials from smaller A-delta fibers. Buchthal became Dean of the Medical Faculty at Copenhagen University in 1962. He was Director of the Clinical Neurophysiology Department at Rigshospitalet, where he instructed many pupils from Europe and the US, until his formal retirement in 1977. But five years later he was invited to set up the neurophysiologic laboratory at the U.S. National Institutes of Health in Washington, DC, which he directed until 1984. He then served as a consultant at Children's Hospital in San Francisco until the age of 90. Buchthal was awarded honorary degrees at the Universities of Munster, Munich (Germany), Zurich (Switzerland), Lund (Sweden), and Wisconsin (US), and was an honorary member of various international societies. He received the Lifetime Achievement Award from the World Federation of Neurology in recognition of outstanding contributions to the knowledge of neuromuscular disorders. "One of the greatest scientists of the last half century in both basic and applied neurophysiology" and "one of the founders of clinical neurophysiology," Buchthal died at the age of 96 in Santa Barbara, California. ${ }^{22,23}$

\section{Collaborators and/or Racial Hygienists}

Carl Vernet (1893-1965) was born as Carl Peter Jensen in Jutland. In 1921 he changed his name to Værnet (at værne, Danish, to protect). Værnet was sought out by the Copenhagen bourgeoisie, because he offered en vogue alternative treatments (e.g. diathermia, the production of heat in body tissues by electric currents, at that time thought by some to be beneficial in treating various neurological and rheumatologic diseases). However his main research interest was the "predominant influence of the neuro-hormonal system on a man's life," and to this end, he also maintained a private animal laboratory. He developed an artificial endocrine gland, a rod-shaped longacting subcutaneous hormonal implant. This "wonder gland [turned] castrated pullets into proud roosters" (Danish newspaper Aftenbladet, 1941); and "men with underdeveloped or abnormal sexual drive could live a normal man's life" (Danish newspaper B.T., 1941). Yet when Værnet's membership in the Danish Nazi party and collaboration with the German occupants became known, his patients abandoned him. Soon his professional and financial base deteriorated. In October 1943, three months after his former clinic had been bombed by the Danish resistance group Holger Danske, Værnet and his family followed an invitation to Berlin. Here, Værnet came into contact with SS-Reichsarzt Dr. Ernst Grawitz, who was a personal assistant to Heinrich Himmler, SS-Reichsführer and German Minister of the Interior. Himmler, determined to eradicate homosexuality from the German gene pool, was fascinated by Værnet's idea to "cure" homosexuals by chronic testosterone substitution delivered through the artificial endocrine gland. Himmler gave an order to "treat Værnet with the outmost generosity. I request a report of three to four pages each month because I am very interested in these things". ${ }^{24}$ Since Berlin was under increasing Allied fire, Værnet relocated to Prague in February 1944, where he was given laboratory facilities and a (formerly Jewish-owned) luxurious apartment. He became a $S S$ Sturmbannfuihrer, and during 1944 Værnet visited Buchenwald 


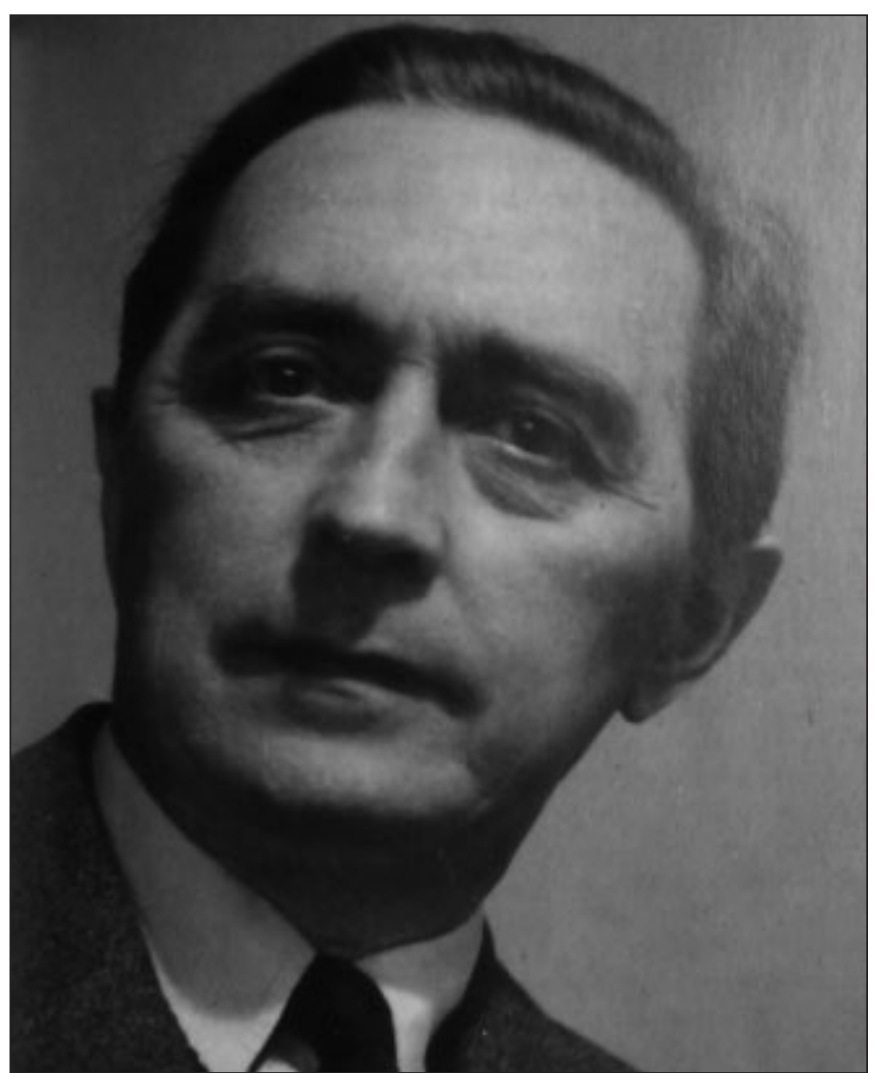

Figure 8: This photo of Carl Varnet (1893-1965) was taken shortly prior to his escape to Sweden (and finally Argentina) in 1947 when he faced charges for war crimes. On the back of the photo, he wrote "dedicated to Kjeld" - his son, Kjeld Varnet (who later became a respected neurosurgeon at Rigshospitalet, Copenhagen) played an important part in facilitating the escape of his father. Photo reprinted by kind permission from Professor Niels Høiby, Department of Clinical Microbiology, Rigshospitalet, Copenhagen University Hospital. Photo originally published in Davidsen-Nielsen H, Høiby N, Danielsen NB, Rubin J. Varnet. Den danske SS-lage i Buchenwald. 1st ed Viby: JP Bøger; 2002.

concentration camp at least four times in order to conduct human experimentation using his artificial gland. Although the fatality rate in Buchenwald exceeded 50 prisoners a day, he reported to his eldest daughter in Prague that it was a "village with a musicfilled square, small cozy shops and people sunbathing." Værnet operated on 17 prisoners in total; according to his requests they included "real homosexuals" and castrated criminal heterosexual offenders. ${ }^{24}$ Not surprisingly, many prisoners hoping for some kind of reward soon reported nocturnal erections and heterosexual fantasies. Yet the lack of scientific evaluation evoked suspicion among leading SS camp officers. Indeed, his final report, delivered by Værnet on February 10, 1945, in Berlin's smoking ruins, refers in detail to his previous work in Denmark but strikingly lacks a detailed account of the Buchenwald experiments. Perhaps in an attempt to distract, Værnet obsequiously praises the addressee:

[As a sign of] deepest admiration and unbreakable loyalty [this report] is dedicated to the SS Reichsfürer, Heinrich Himmler, embodiment and guarantor of the national socialist, Nordic-Germanic way of life - in gratitude for his active comprehension [...], continuing interest and generous assistance, and with hope that [...] the present work [will be of] benefit to the German people. $^{24}$

On his return to Copenhagen Værnet was arrested. With the help of his eldest son Kjeld Værnet, however, he convinced the Danish authorities that his release was indispensable because of a "life-threatening heart condition" (which later miraculously resolved by itself) and the "utmost importance" of the artificial endocrine gland that promised "tremendous export revenues [to the Danish state] of more than one Billion Danish kroner." On behalf of his father, Kjeld Værnet conducted negotiations with 'a large British-American pharmaceutical company' concerning the takeover of the artificial gland. Although these negotiations failed, Kjeld Værnet was successful in facilitating his father's final escape to Argentina via Stockholm (Figure 8). Værnet arrived in Buenos Aires in March 1947. "Carlos Pedro Varnet" became an Argentine citizen and worked as a general practitioner until his death in $1965 .^{24}$ Two attempts by Værnet junior to negotiate impunity and enable his father's return to Denmark failed. Kjeld Værnet (1920-1999) was a respected neurosurgeon at Rigshospitalet for 30 years.

Herman Bernhard Lundborg (1868-1943) was born in Värmland, Sweden (Figure 9). Having studied in Sweden,

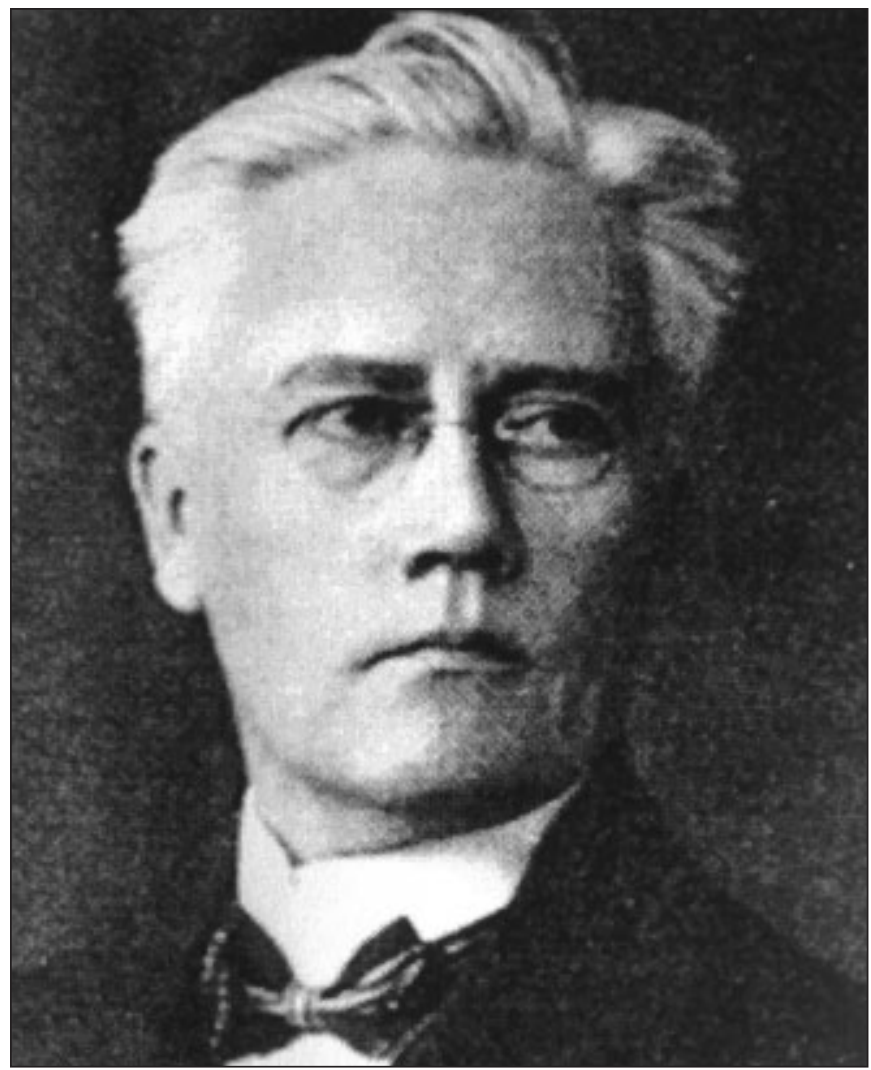

Figure 9: Herman Lundborg (1848-1943). (This picture is now in the public domain.) 


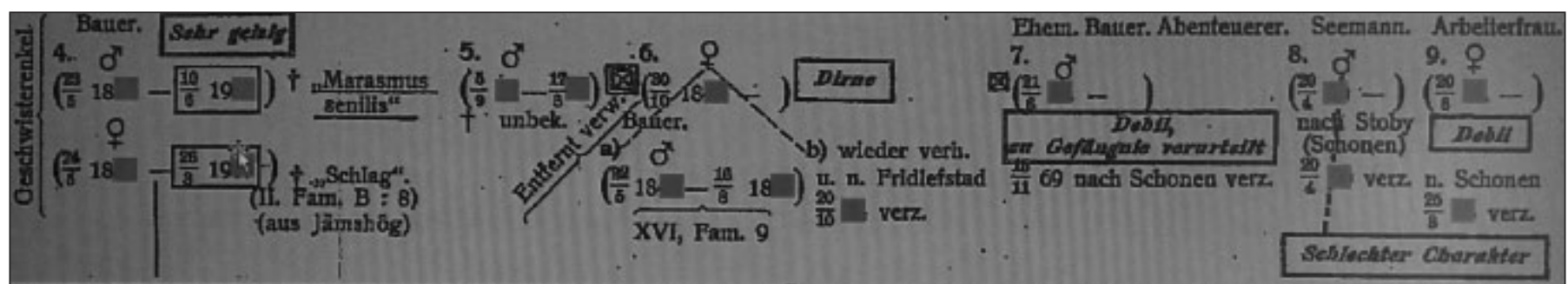

Figure 10: In his thesis Herman Lundborg described a family from Southern Sweden with progressive myoclonic epilepsy (Unverricht-Lundborg disease) and argued for an association between low social status and un-Germanic physiognomy and racial features. Sehr geizig - very stingy; Dirne - whore; schlechter Character - bad character. Reprinted from: Lundborg H. Die progressive Myoklonus-Epilepsie (Unverricht's Myoklonie). Uppsala:Almqvist \& Wiksell; 1903. (This photo is now in the public domain.)

Norway, the Netherlands and Germany, he graduated from Lund University in 1903. In his doctoral thesis Lundborg described a family from Listerland (Southern Sweden) with progressive myoclonic epilepsy, now known as Unverricht-Lundborg disease..$^{25,26}$ Using Mendel's laws and pathological case studies, he concluded that the family suffered from a recessively inherited, progressive degenerative disorder due to the high prevalence of "unwise marriages." He traced the family tree and the first manifestations of the disorder back to the 18th century, an unprecedented achievement at that time. Lundborg concluded that the Listerland people were "genetically degenerated," not realizing that cousin marriages were a way to overcome the splitting of farm land into increasingly smaller and unviable units during the process of inheritance from one generation to the next. In his thesis Lundborg argued for an association between low social status and un-Germanic physiognomy and racial features (Figure 10). In 1925, Lundborg became Associate Professor of Psychiatry and Neurology in Uppsala. In 1922, one year prior to the establishment of the first professorship for racial hygiene in Germany, he became Professor for Racial Hygiene and Director of the State Institute for Racial Biology in Uppsala. In 1933 he was elected Vice-President of the International Federation of Eugenics and elected an Honorary Member of the Academy of Sciences in New York in 1935. Lundborg wrote several large opuses on racial hygiene and eugenics both for a scientific and layman readership, e.g., The danger of degeneracy, ${ }^{27,28}$ The racial character of the Swedish nation, ${ }^{29}$ Race biological aspects of some problems of population, ${ }^{30}$ and Western civilization in jeopardy. ${ }^{31}$ In addition to the influence of eugenics and racial hygiene in Lundborg's writings, one can easily detect the influence of Nordic chauvinism and Doomsday scenarios also:

The race, the efficiency of the race, has deteriorated. Degeneration spreads quickly around, takes fast hold and expresses itself in the worship of mammon, love of pleasure, degradation, [...] and crime. [...] A glaring waste of the national material is to be found at present among many of the civilized nations and even with us. Material of great and to a large extent irreplaceable value is being lost with alarming rapidity. [...] Race-mixtures [lead to a] nation of inferior quality. This must sooner or later overthrow the ancient civilization of the country. Chaos and anarchy become the ruling powers. ${ }^{27,28}$

The Swede, [similarly to] members of other Scandinavian nations, is everywhere a welcome stranger.
He becomes the pioneer, and as a rule, lays the foundation of a solid, organized state. There are many people with a weaker heritage who have not been capable of this. [...] Human beings are, after all, subject to the laws of heredity, and we cannot ignore these without being crushed by them. Eugenically good human stock is an absolute necessity for the attainment of genuine, lasting culture. [...] To attain this end, more profound care is needed, [... ] raising of the nativity rates in eugenically favorable strata, [...] and finally, diminishing the fertility of the unfit, in short, eugenical measures of various kinds. ${ }^{31}$

Lundborg worked hard to establish racial hygiene as a branch of academic medicine and to promote its political use to "prevent the degeneration" of the "genetically superior Nordic Race." He lobbied the public (e.g. by publishing a series of cheap pamphlets on eugenics, often given away free of charge, and by touring Sweden in 1919 with the exhibition "Swedish Racial Types"), the political establishment (e.g. by distributing largesized, high quality "eugenic atlases") and fellow scientists (e.g. by introducing "Race Biology" at the Scandinavian Scientific Meeting in Gothenburg in 1923). He emphasized both positive eugenics (that is, enhancing the genetic quality by conscious selection or introduction of "advantageous" genes), negative eugenics (that is, to prevent the transmission of "disadvantageous" genes by e.g. sterilization) and the necessity to decrease the financial burden of caring for the unfit - "it behooves us to become advisers and helpers to race and peoples." When his commitment was rewarded by the creation of the State Institute for Racial Biology in Uppsala in 1922 with him as its Head, his Nazi-friendly and Nordic-chauvinistic standpoint became the officially sanctioned interpretation of eugenics in Sweden. Not surprisingly, Lundborg was openly committed to Nazi ideology in the 1930s, and he also expressed anti-Semitic views. In 1936, the Medical Faculty of Heidelberg University rewarded Lundborg with an honorary doctorate for being "among the premier racial hygienists of science" and "a friend to Germany". ${ }^{32}$ Lundborg was co-founder of the Riksföreningen Sverige-Tyskland (Swedish-German National Society), established in Lund in 1937, that worked "for a fair judgment of the New Germany, without partisan politics, seen from an entirely Swedish point of view." 33 Lundborg died in Östhammar, near Stockholm.

Thorleif Dahm Østrem (1898-1980) was a consultant neurologist at Oslo Hospital. In April 1940 he was one of only ten Norwegian physicians who were members of the Nasjonal 


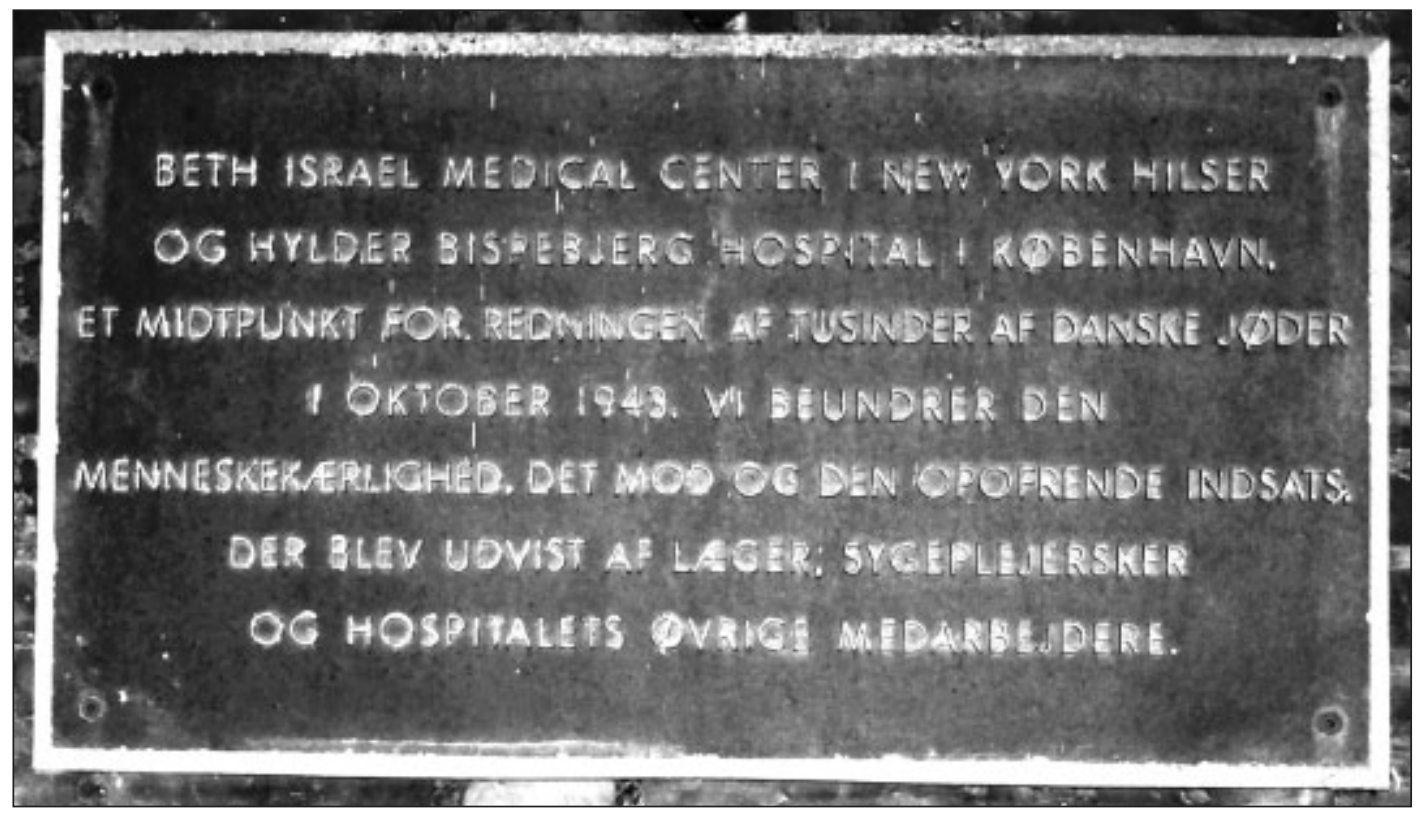

Figure 11: This plaque at Bispebjerg Hospital, Copenhagen, was given in recognition of its outstanding contribution during the rescue of the Danish Jews in October 1943. "Beth Israel Center in New York applauds and greets Bispebjerg Hospital in Copenhagen, a center for the rescue of thousands of Danish Jews during October 1943. We admire the philanthropy, courage and devotion of the doctors, nurses and other hospital staff." (Photo by the authors)

Samling, the Norwegian fascist party whose leader Vidkun Quisling became minister-president of the collaborationist government in German-occupied Norway. ${ }^{16}$ A dedicated racial biologist, Østrem served as director of health in Quisling's regime from 1940-1945. Østrem was clearly against "inferior groups" and "foreign racial elements," including the Sami people, becoming "further integrated into the Norwegian population." ${ }^{34} \mathrm{He}$ passed strict sterilization laws and argued that only individuals who could "keep or improve the hereditary quality of the race" should be "awarded the right to give life." 35 Østrem believed that neurological expertise was essential for decision making in forced sterilization, probably because many of the children and adults in question had brain disorders such as epilepsy, schizophrenia and cerebral palsy. ${ }^{16}$ In addition, Østrem tried to establish a "euthanasia" program akin to the notorious Action T4 program in Germany, during which more than 275,000 physically or mentally handicapped children and adults were killed. ${ }^{36}$ However, such a program was never established in Norway, and Østrem's eagerness was deemed inappropriate and radical even by German officials. During the legal purge in Norway after WWII Østrem was sentenced to four years of forced labor. Following this, Østrem returned to his profession and worked largely undisturbed as a neurologist in private practice. ${ }^{37}$

\section{DiscuSSION}

All listed physicians, except for Værnet and Østrem, have made lasting contributions to the field of neuroscience. In addition, their biographies reflect a range of possible responses to the Nazi occupation of Scandinavia during WWII - from active resistance and escape to collaboration.
The activities of resistance fighters such as Fog, Thygesen, Sæthre and Jansen appear exceptional at first, but many hundreds of Danish and Norwegian physicians opposed the German occupants, especially in saving Jews. When Buchthal fled in September 1943 (the day after the planned round-up of Danish Jews had been leaked from the Germans), he was in fact ahead of the large wave of Danish Jews escaping to Sweden. Sweden announced it would accept all Danish refugees only after Buchthal's fellow refugee, Niels Bohr, had negotiated with the Swedish king, Gustav V. During October 1943 a complex network of general practitioners, hospital-based physicians, nurses, non-medical hospital staff and many others enabled 7200 Danish Jews to escape from the Greater Copenhagen area; only 481 Jews were caught and deported to Theresienstadt concentration camp. Bispebjerg Hospital in Copenhagen alone saw 2000 Jews pass its doors on the way to Sweden (Figure 11). General practitioners systematically made house visits to urge their Jewish patients to go to Bispebjerg or another of Copenhagen's hospitals, where they were admitted under false names and with fabricated diagnoses, received meals and beds, until the organizing working group at Kommunehospitalet (a hospital in the city center) had organized a boat transport over the Sound. Apart from dedicated support from the entire population (e.g. taxi drivers had to drive refugees to harbors, fishermen had to provide their boats) and money (for instance, the Danish Medical Association raised 1,000,000 kronor for the Bispebjerg refugees), creativity, boldness and luck were needed:

One night $[\ldots]$ we received a message that Bispebjerg Hospital was surrounded by Germans [and] rightly, the entrances were guarded by German police [...], who searched all ambulances driving from and to the hospital 
[...]. Since we had 200 refugees at Bispebjerg Hospital that night, the situation was not too encouraging. [...] We needed to evacuate all refugees [but] because of the German guards we could not remove the Jews from the hospital. [Therefore] we relocated them to the nurses' dormitories, where we thought they would be safer [in case of a] German raid during the night. [In the morning] at $9 \mathrm{AM}$, a funeral procession left the chapel [...]. The procession included 20-30 taxi cars with refugees [...]. Everything went well, and the refugees, who had not been aware of the threat, had all spent a quiet night at the nurses' dormitories. ${ }^{38}$

The biographies of Værnet, Lundborg and Østrem reveal similarly interesting insights into the circumstances that affected Scandinavian neuroscience during WWII. Værnet, as far as it is known, never specifically commented on his activities in Buchenwald, nor did he publicly show any signs of regret or remorse. One can only speculate as to why he chose to conduct human experiments using concentration camp prisoners. Similar to German neuroscientists who collaborated with the Nazi regime, ${ }^{36,39}$ career opportunism, scientific idealism, and indoctrination by Nazi ideology likely played a role, as well as the destruction of his professional and financial basis in Denmark. Whereas Værnet's war crimes are unparalleled in the Nordic countries, Lundborg and $\emptyset_{\text {strem and their racial }}$ hygienist views reflect a more common, though equally controversial part of recent Scandinavian history. The "Norwegian Program for Race Hygiene" had already been presented in Oslo in 1908. Two years later the Swedish Society for Racial Hygiene was founded; a large number of its members were also registered in the equivalent German society (which testifies to the close links to the German movement). ${ }^{40}$ The Nordic sterilization laws, introduced a few years after the creation of the State Institute for Racial Biology in Uppsala in 1922 , became a high point in the implementation of eugenics in Scandinavia. The parliaments in Denmark (1929), Sweden (1934) and Norway (1934) passed these laws almost unanimously (in contrast, proposals for similar laws were rejected in, among others, Britain and the Netherlands). Germany implemented sterilization laws in 1933 after the Nazi takeover, soon followed by "euthanasia" programs and the systematic killing of adults and children with neurological and psychiatric diseases, and, finally, the Holocaust. Fortunately, Scandinavian countries never descended the slippery slope from forced sterilizations to "euthanasia"; yet, eugenic sterilization in Sweden reached its height as late as 1945, when 1318/1747 sterilizations were carried out for "eugenic" (as compared to "medical" or "social") indications..$^{40,41}$

\section{Conclusions}

Scandinavian neuroscience during WWII was not isolated from the political turmoil and Nazi oppression; rather it was dramatically affected by the events during the German occupation from April 1940 to May 1945. When comparing the activities and fates of Scandinavian neuroscientists with those of their colleagues elsewhere in Europe, including Germany and Austria, the most striking observation is the high ratio of resistance fighters to collaborators and victims. As outlined above, resistance was widespread among the entire medical community in Denmark and Norway, and the number of Jews (and thus, the number of Jewish physicians) deported from the two countries was relatively low compared to the rest of Nazioccupied Europe. In contrast, the persecution of Jews and others had deprived Germany and Austria of numerous world-leading neuroscientists, and "Aryan" physicians had been able to take attractive vacant posts. Therefore, as has been pointed out by Shevell, a symbiotic relationship developed between these physicians and the Nazis. ${ }^{42}$ With few exceptions (including the cases of Værnet and Østrem), such a symbiosis never existed between the German occupiers and the medical community in Scandinavia. Of course, similar to neuroscientists in other parts of Europe during the Nazi era, many Scandinavian neuroscientists were neither resistors nor collaborators. ${ }^{36,39,43,44}$ Some likely went about their daily routines and didn't become involved at all, whereas others might have helped the resistance on some occasions and been collaborators in other instances.

Georg Herman Monrad-Krohn (1884-1964), preeminent Norwegian neurologist and Dean of the medical faculty at Oslo University during 1940-1945, for instance, tried to keep the medical faculty free of Nazis and protested loudly when NSstudents and members of the Norwegian Legion were prioritized during enrollment at the university. Yet in November 1943 when the Nazis closed the university, in an attempt to maintain order Monrad-Krohn forbade students to leave his lecture despite several warnings that German soldiers were approaching, which led to the deportation of all of these students to Buchenwald concentration camp. ${ }^{16}$

\section{ACKNOWLEDGEMENTS}

The authors thank the staff of the Departments of Neurology, Neurophysiology and Neurosurgery at Rigshospitalet, Copenhagen University Hospital, for providing information on Fritz Buchthal, Mogens Fog, Erik Skinhøj, Poul Thygesen, Carl Værnet, and Kjeld Værnet. Especially, they thank Professor Christian Krarup, Department of Neurophysiology, Rigshospitalet, Copenhagen University Hospital, for information on Fritz Buchthal and his kindness in providing Buchthal's unpublished biography. They also wish to thank Professor Niels Høiby, Department of Clinical Microbiology, Rigshospitalet, Copenhagen University Hospital, for information on Carl Værnet and for kind permission to reprint Værnet's portrait. Moreover, the authors wish to acknowledge the help of Dr. Benjamin Rix Brooks at the Department of Neurology, Carolinas Medical Center and University of North Carolina School of Medicine, who provided papers and information on Henrik Hartmann, and Dr. Andreas Puschmann, Department of Neurology, Lund University Hospital, Lund, Sweden, for providing the figure from Herman Lundborg's thesis. 


\section{REFERENCES}

1. Bak SL. From rescue to escape in 1943: De-victimizing the Danish Jews. Paper presented at the congress "Towards an integrated perspective on Nazi Policies of Mass Murder;" Oslo, Norway; June 20-21, 2009.

2. Christensen CB, Lund J, Olesen NW, Sørensen J. Danmark besat. Krig og hverdag 1940-45. 4th ed. Copenhagen: Informations Forlag; 2009.

3. Dahl HF, Kirchhoff H, Lund J, Vaale LE, editors. Danske tilstande norske tilstande 1940-45. 1st ed. Copenhagen: Gyldendal; 2010.

4. Aarli JA, Stien R. The history of neurology in Scandinavia. Handb Clin Neurol. 2010;95:657-66.

5. Fog M. Efterskrift 1904-45. 1st ed. Copenhagen: Gyldendal; 1976.

6. Fog M. Første illegale brevet. Dokumentationsarkivet, Frihedsmuseet, Copenhagen; 1942.

7. Møller M. Mogens Fog. Fra Modstandshelt til landsforræder. En biografi. 1st ed. Copenhagen: Gyldendal; 2009.

8. Thygesen P. Læge i tyske koncentrationslejre. 1st ed. Copenhagen: Thanning og Appel; 1945.

9. Anonymous. Kommentar zu Poul Thygesen - Arzt im Konzentrationslager. Nordfriesland. 1982;16:63-4.

10. Thygesen P. The concentration camp syndrome. Dan Med Bull. 1980;27:224-8.

11. Zeidman LA. Dr. Haakon Sæthre: A Norwegian Neuroscientist and his Resistance against Nazi Germany. J Hist Neurosci. 2013;22: 160-73.

12. Sæthre H. Über den Turmschädel, seine Erblichkeit, Pathogenes und neuropsychiatrischen Symptome. Acta Psych Neurol Scand. 1931;6:405-7.

13. Sæthre H. Ein Beitrag zum Turmschädelproblem (Pathogenese, Erblichkeit und Symptomatologie). Deutsch Zeitschr Nervenheilk. 1931;117:533-5.

14. Chotzen F. Eine eigenartige familiäre Entwicklungsstörung. (Akrocephalosyndaktylie, Dysostosis craniofacialis and Hypertelorismus). Monatsschr Kinderheilk. 1932;55:97-102.

15. Gogstad AC. Helse og hagekors. Helsetjeneste og helse under okkupasjonsstyret i Norge 1940-1945. 1st ed. Bergen: Alma Mater Forlag AS; 1991.

16. Stien R, Aarli JA. Hjernens leger - historien om de første norske neurologer. 1st ed. Oslo: Den norske nevrolitterære klubb; 2012.

17. Cohen MM, Vidaver D. Asbjørn Følling. In: Ashwal S, ed. The Founders of Child Neurology. 1st ed. San Francisco: Norman Publishing; 1990.

18. Cohen MM, Vidaver D. The man behind the syndrome: Sigvald Refsum. J Hist Neurosci. 1992;1:277-84.

19. Cohen MM, Vidaver D. Two Norwegian neurological giants: Georg H Monrad-Krohn and Sigvald Refsum. J Med Biograph. 1989; 6:194-9.

20. McIntosh J. Transcript of an Oral History Interview with Henrik A. Hartmann, Norwegian, Engineer, Swedish Army, World War II. Conducted via the Wisconsin Veterans Museum Research Center, Madison, WI; 2000.

21. modstand.natmus.dk/Person.aspx?15965 [homepage on the Internet] Copenhagen:Frihedsmuseet [cited December 28, 2012]. Available from http://www. modstand.natmus.dk/.

22. Pinelli P. A tribute to Fritz Buchthal. Neurol Sci. 2004;25:38.

23. Horowitz SH, Krarup C. Obituary. Fritz Buchthal, MD. Muscle Nerve. 2004;30:1-2.

24. Davidsen-Nielsen H, Høiby N, Danielsen NB, Rubin J. Værnet. Den danske SS-læge i Buchenwald. 1st ed Viby: JP Bøger; 2002.

25. Lundborg H. Die progressive Myoklonus-Epilepsie (Unverricht's Myoklonie). 1st ed: Uppsala: Almqvist \& Wiksell; 1903.

26. Unverricht H. Die Myoclonie. 1st ed Wien: F. Deuticke; 1891.

27. Lundborg H. The danger of degeneracy. Eugenic Rev.1922;13: $531-9$.

28. Lundborg H. The danger of degeneracy, II. Eugenic Rev. 1922;14: 41-3.

29. Lundborg H, Linders FJ (eds.) The Racial Character of the Swedish Nation. Uppsala: Anthropologia Suecica MCMXXVI. Swedish State Institute for Race Biology; 1926.

30. Lundborg H. Race biological aspects of some problems of population. Eugenic Rev. 1928;19:290-3.
31. Lundborg H. Västerlandet i fara: befolkningsfrågor i biologisk och rashygienisk belysning. Göteborg: Ernst V. Hansson; 1934.

32. Rodenwaldt E. Letter to Schneider C, December 11, 1935; UAH, B1523-5, cited in S.P. Remney. The Heidelberg Myth: The Nazification and Denazification of a German University. 1st ed. Cambridge, MA: Harvard University Press; 2003.

33. Hansson MG, Nilsson PM. Läkarmedlemmar i Riksföreningen Sverige-Tyskland 1937-1945: vilka och varför? Svensk Medicinhist Tidskr. 2007;11:151-64.

34. Haave P. Sterilisering av tatere 1934-1977. Norges forskningsrad; 2000.

35. Østrem, T. Fra negativ til positiv befolkningspolitikk. In: Østbye HN, editors. Det nye Norge. Oslo: Blix; 1941.

36. Zeidman LA. Neuroscience in Nazi Europe Part I: Eugenics, Human Experimentation, and Mass Murder. Can J Neurol Sci. 2011;38:696-703.

37. Berg O. Spesialisering og profesjonalisering. En beretning om den sivile norske helseforvaltnings utvikling fra 1809 til 2009. Helsetilsynet; 2009

38. Lund S. Lægerne og Jødeflugten. In: Svendstorp A, editor. Den hvide brigade. Danske lægers modstand. Copenhagen: Carl Allers Bogforlag; 1946. p. 175-202.

39. Kondziella D. Thirty neurological eponyms associated with the Nazi era. Eur Neurol. 2009;62:56-64.

40. Roll-Hansen N. Eugenic sterilization: A preliminary comparison of the Scandinavian experience to that of Germany. Genome 1989; 31:890-5.

41. Björkman M, Widman S. Selling eugenics: The case of Sweden. Notes Rec R Soc Lond. 2010;64:379-400.

42. Shevell M. Neurosciences in the Third Reich: from ivory tower to death camps. Can J Neurol Sci. 1999;26:132-8.

43. Zeidman LA. Neuroscience in Nazi Europe Part II: Resistance against the Third Reich. Can J Neurol Sci. 2011;38:826-38.

44. Zeidman LA, Kondziella D. Neuroscience in Nazi Europe Part III: Victims of the Third Reich. Can J Neurol Sci. 2012; 39: 729-46. 